\title{
Income Inequality, Poverty and Economic Growth in Chile: The Years of the Coalition of Parties for Democracy.
}

\author{
Jorge Rojas-Vallejos* \\ PONTIFICIA UNIVERSIDAD CATÓLICA DE VALPARAÍSO
}

\begin{abstract}
The aim of this article is to provide insight on the relationship between income inequality, poverty, and economic growth for Chile during the administrations of the Coalition of Parties for Democracy (CPD) from 1989 to 2010. This study described the evolution of the Chilean economy and relates its behavior to the political transition experienced by the country. We build a model to analyze whether there is political cooperation in this period and why. Last, we observe that for Chile, economic growth alone is not enough to alleviate inequality problems, but it plays a major role in reducing poverty.
\end{abstract}

Keywords: income inequality, poverty, economic growth, political economy

\section{RESUMEN}

El objetivo de este artículo es proveer conocimiento sobre la relación entre la desigualdad de ingreso, la pobreza y el crecimiento económico de Chile durante los ańos de los gobiernos de la Concertación de Partidos por la Democracia desde 1989 a 2010. Este estudio describe la evolución de la economía Chilena y relaciona su comportamiento con la transición política experimentada por el país. Se construye un modelo para analizar si existe cooperación política en este período y por qué. Finalmente, se observa que para Chile, el crecimiento económico por sí sólo no es suficiente para aliviar los problemas de desigualdad, pero sí tiene un rol fundamental en la reducción de la pobreza.

Palabras Clave: desigualdad ingresos, pobreza, crecimiento económico, economía política

JEL Codes: C80, D31, P260

*jorge.rojas@pucv.cl 


\section{INTRODUCTION}

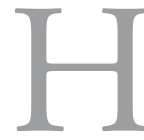

ow does political cooperation impact on inequality, poverty and economic growth? Understanding how political cooperation works on these variables could provide valuable insight to increase overall welfare in society. To answer this question, we study the case of Chile. This country is an interesting case to discuss because of its transition from political dictatorship to a democratic competitive system in the late 80 s and early 90s. For example, the Political Constitution written during the dictatorship was preserved, the former dictator remained as Commander in Chief and the new democratic elite returned to Chile after living many years in exile, mostly, in advanced capitalist countries. Notice that many members of this elite were socialists and communists when they went into exile. So, there were many questions about the approach this elite could choose.

In this paper, we focus on the macroeconomic indicators for Chile during the years that the Coalition of Parties for Democracy (CPD) run the government uninterruptedly, that is, from 1989 to 2010. The main question is whether there was political cooperation between the opposed political sectors or not. All this, in the context of a transitioning country with challenges such as economic growth, poverty and inequality.

Income inequality, economic growth and political institutions are highly integrated. We could describe them as coupled dynamic systems in which each isolated system depends on what is happening in the other ones. Of course, the relationships between all variables show in figure (1) may be present in multiple directions. We highlight in this article the strongest and most sensical. We start with the inequality node. For historical reasons, we may argue an initial inequality distribution. In the case of Chile, this initial inequality distribution can be measured in either income or wealth, and its origin could be related to migration from Spain at the beginning of the colonial era. During this period, native Chileans were subjugated by the military power of the invaders. Through consecutive historical events such as revolutions, civil wars and civil 
rights movements, the initial inequality evolved to the one observed in recent times in which native Chileans are still behind non-native groups, but there are also a large middle class.

High levels of inequality are negative for efficiency. The main mechanism is the distortion of choices and incentives as described by Atkinson, Stiglitz and others. Therefore, this efficiency loss would impact on productivity and this onto the overall economy. This micro shock would affect different sectors in the economy slowing down growth, not letting the economy realize its full potential. There is sufficient evidence to support that economic growth tends to decrease poverty, but its impact on inequality is much less clear. This artificial decrease in economic growth has two effects. First, it makes harder to eliminate extreme poverty. Second, it limits the amount of available resources to alleviate the inequality problems. Nevertheless, a caveat is in place. China and other developing economies such as Chile and Brazil have experienced high rates of economic growth, decreasing absolute poverty, but increasing inequality in the case of China, and leaving unchanged the inequality levels for Chile and decreasing them very slightly for Brazil over the last two decades. This could be seen as a sign that market forces are not enough to solve the inequality problem, and hence some political reforms are needed.

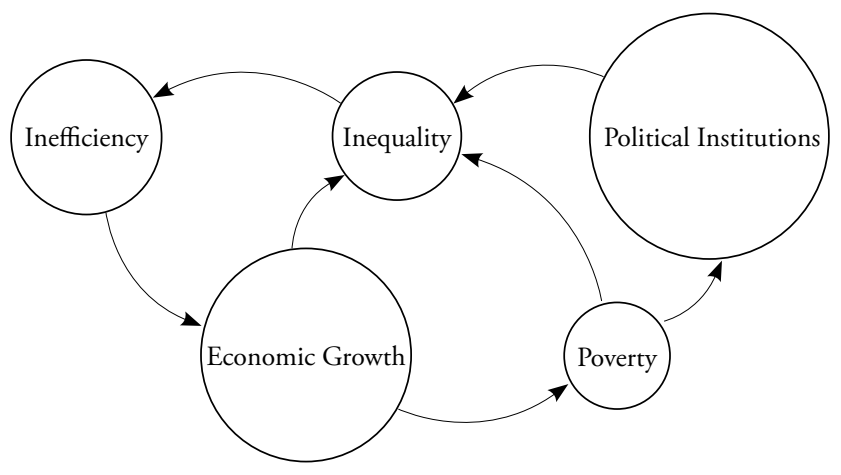

Figure 1. Main interactions in the socio-economic system.

Notes: Notice that the relative size of the circles show relative importance of the variable, while dashed lines means feedback relations. 
Similarly, poverty also impacts on inequality because of the unequal access to education and health care. In a capitalist society in which most services are traded as consumption goods, and taking into account that many developing countries provide poor-quality public services compared with the ones provided by the private sector, a small income difference among the poor may create large differences in the longer run. For instance, a poor family with one child may provide a slightly better education than a similar family with two children. This results in one family with double disposable income for education, holding anything else constant. Usually the returns to education, particularly, higher education are very large. Thus, a young person who makes it to college may achieve a much better standards of living in her adulthood than her neighbor who did not get into college.

Beyond this contribution of poverty to inequality there is another factor to be analyzed, that is, Politics. Poor families in their struggle for survival tend to ask their children to work. These children might attend primary school and even high school. These public schools have low quality standards at any international measure. Thus, these children devote little time to their learning process and hence their critical thinking is poorly developed. Once they become citizens, they tend to have little understanding of the impacts of public policies on their lives, and therefore, they lack the necessary tools to promote change in their societies. This lack of knowledge and skills in turn helps to maintain the status quo. Hence, there are no profound institutional reforms. Unless, there is an exogenous shock, such as: revolutions, civil wars or coup d'états that are able to introduce important structural reforms.

Political institutions with economic growth play a major role to eliminate unfair inequality. By unfair inequality should be understood the idea of being paid an amount smaller that the marginal productivity of labor, capital or any other factor of production as well as not developing the full potential and skills of a person.

The globalized world has observed that economic growth by 
itself does not solve inequality. Economic growth is a necessary condition, but not sufficient. Moreover, the legal framework and the initial conditions of a given economy are essential to effectively address the inequality problem. We find that for a country to move forward economically and socially; political cooperation is crucial and this is the case of Chile during the years of the Coalition of Parties for Democracy.

The remainder of the paper is structured as follows. Section 2 discusses some related literature, while Section 3 summarizes some stylized facts about Chile for the period 1989-2009. Section 4 presents the theoretical framework and discusses its results, while Section 5 concludes.

\section{Related Literature}

First, we review the literature related to economic growth and inequality in a macroeconomic level, namely, the different neoclassical approaches to answer the question about whether inequality is harmful for economic growth or not. Then, we look at the literature associated with the micro-determinants of poverty and inequality, informational economics and their interactions with economic growth and efficiency. Finally, we address some literature on political cooperation and public policy trying to understand the importance of political stability for distribution and economic activity.

In modern societies the positive relationship between educational attainment and income is well established. For instance, Barro and Lee (2001) find that in 2000, members of advanced economies achieve an average of 9.80 years of schooling, as compared with only 4.89 years for those from developing countries. Lucas (1988), Barro (1991) and Benhabib and Spiegel (1994) show that there is sufficient evidence to claim that human capital and education are important driving forces in the determination of growth. There is much less consensus on the relationship between income distribution and growth. In the 1990's, theoretical and empirical studies emerged showing that inequality would be negatively 
associated with growth across countries, including Bertola (1993), Alesina and Rodrik (1994) and Persson and Tabellini (1994). On the other hand, researchers such as Li and Zou (1998) and Forbes (2000) report findings with the opposite sign. At the same time, Barro (2000) finds evidence of a negative effect of income inequality on growth for poor countries, whereas a positive relationship for rich countries, with only a weak overall effect of inequality on growth and investment. A third position is described by Rehme (2007) who finds evidence of a U-shaped relation between education and growth, with increases in education leading to first increases then decreases in growth as well as income inequality. In other words, this issue has important policy implications, since different assumptions about the channels between growth and inequality tend to produce different outcomes for the poor, see Deininger and Squire (1997). More recently, Rojas-Vallejos and Turnovsky (2017) find that the econometric model specification may induce all these signs. Hence, the empirical methodology must allow for causal inference and be robust to the usual criticism of endogeneity.

Alesina and Rodrik (1994) study the effect of income inequality on economic growth through a neoclassical framework in which agents maximize utility continuously along their lives and do not differ in their levels of human capital. They find that the decrease in economic growth is not directly related to income inequality but rather the fiscal and taxation policies implemented by governments to address the problem. In their model, taxes were the responsible for less economic growth since governments with high levels of inequality tend to increase taxes and use them to redistribute income. Bertola (1993) develops a model with a representative agent of infinite life, focusing on growth and distributional effects of fiscal policy through taxes and subsidies. Persson and Tabellini (1994) work with an overlapping generations model with two periods of life and agents who have different skill endowments. They focus on the political equilibrium of society and conclude that inequality leads to policies that do not protect property rights, and hence through this channel there is a decrease in economic growth. 
Rehme (2007) contends that while most empirical work focuses on linear relationships, the growth-inequality relationship may in fact be nonlinear. He argues that both growth and measured inequality can be represented as inverted U-shaped functions of the percentage of high-skilled people in the population that represents the stage of development. This could explain why the growth-income inequality relationship is so di cult to predict, since the sign of the association depends upon where each particular economy lies, in terms of its percentage of high-skilled people relative to the turning point of its growth and inequality functions.

The above review is addressing the macroeconomic characteristics of the problem. However, some may argue that there is "too much" aggregation to obtain real insight about the true mechanisms in which economic growth influences the time path of poverty and income inequality. Albertus and Menaldo (2016) discuss that the distribution of income and wealth depends upon the political preferences of the group who is in power rather than the political system itself. That is, whether the regime is democratic or autocratic, what matters the most is how the political elite behaves to maintain social stability. This adds another layer of complexity to the question because now we must consider political behavior in addition to the economic system. Most of the economic literature abstracts from this element of reality.

To support this point, let us see an example. Using data from the World Bank, we see that Chile has experienced an economic growth of around 5\% per year between 1989 and 2009, and the reduction in poverty, measured as the national poverty line, has dropped from $40 \%$ in 1989 to $15 \%$ in 2009 . At the same time, income inequality has remained stable around a Gini index of 50 points, being 52.1 in 2009. For China, we observe that growth has been at a rate close to 10\% per year, and absolute poverty has dropped from 84\% in 1987 to $30 \%$ in 2008 . Nonetheless, income inequality grew from a Gini index of 32.4 in 1990 to 42.5 in 2005 . From these two cases alone, we may not find conclusive answers about the linkages between income inequality, poverty, growth and political systems. The only 
one thing more or less clear is that growth tends to reduce poverty, and this is strongly supported in the economic literature as well.

To understand these seemingly contradictory results, we review some microeconomic literature. Lockwood and Manning (1988) explore inequality in information with individuals who have the same level of ability and the same probability to get into a given occupation, i.e., equality of opportunity. They show that these different levels of information lead to inefficient economic outcomes, even in the presence of equality of opportunity. More-over, they show that under reasonable assumptions with heterogenous individuals with asymmetric information, it may be the least productive individuals who become managers, and hence the decline in productivity and the worsening in inequality. Richer households tend to have access to more and better information. Thus, access to information plays a significant role not only for economic growth, but also for distribution.

Some microeconometric studies shade light on these interlinkages. Weller (2007) shows that for industrializing countries a progressive income taxation system may result in a more equitable income distribution with higher revenues, less financial and economic volatility, and faster growth. The mechanism that explains these findings is basically a strong formal economy. Wodon (2000) does a micro-oriented analysis of poverty and inequality for Bangladesh using household level data of five national surveys. He runs the analysis with poverty data decomposed by regions, i.e., he computes Gini indices at the rural, urban and national levels. His main finding is that education in urban areas and land in rural ones are the two variables that better explain inequality. In a similar fashion David and Marouani (2012) study the Syrian case. Krstic and Sanfey (2011) do a similar analysis for Serbia, but taking into account the informal economy. Goudie and Ladd (1999) describe the interactions and feedbacks between economic growth, poverty and inequality discussing the policies developed by governments to address all three variables.

Mayer (2010) and Fleisher et al. (2005) analyze the effects 
of schooling and the returns to higher education on inequality, respectively. Mayer (2010) focuses her analysis in the USA, while Fleisher et al. (2005) do it for China. Both achieve the conclusion that higher educational attainment, on average, improves earnings. Hence, a reasonable, plausible and simple conclusion is that one way to decrease income inequality may be through public policies oriented to increase the higher educational attainment of lowincome and middle class families. Fan (2008, Ch. 2) provides the methodology to study public spending in developing countries explaining in great detail where and how to get the data, and the econometric tools to be used in running the analyses, namely, the generalized method of moments (GMM) and panel data.

For the specific case of Chile, Contreras (2003) focuses his analysis on inequality and poverty and its relationship with the rapid economic growth experienced by Chile between 1990 and 1996. He uses parametric and non-parametric methods to address a similar question to ours but ignoring political behavior. Using the Datt-Ravallion decomposition, Contreras finds that the $85 \%$ of the reduction in poverty may be attributed to economic growth. Then, he concludes that although inequality remains the same, poor and rich are better o in absolute terms. Agostini, Brown and Roman (2010) focus their analysis on ethnic groups rather than the usual regional or zonal approach. They use bootstrapping to simulate values of household income, and this complete set of simulated values is then used to calculate the headcount ratio and Gini coefficients for each ethnicity represented in the population. They find that indigenous groups tend to be poorer than non-indigenous Chileans, while within-income inequality is lower for these groups.

\section{STYLized FaCts}

according to Schneider (2002), the size of the informal economy in Chile was around $19.8 \%$ in 2000 . So, keeping this value in mind, the household data are expected to be reliable for the period of time to be analyzed. These data sets have been obtained from the Encuesta de Caracterización Socioeconómica Nacional (CASEN 
Survey), a periodic survey undertaken by Chile's Ministry of Social Development.

Table 1. Annual growth of macroeconomic indicators for CHILE, I 990-2009.

199019921994199619982000200320062009

\begin{tabular}{lccccccccc}
\hline GDP growth & 3.7 & 12.3 & 5.7 & 7.4 & 3.2 & 4.5 & 3.9 & 5.7 & -1.0 \\
Population growth & 1.8 & 1.9 & 1.8 & 1.5 & 1.3 & 1.2 & 1.1 & 1.0 & 1.0 \\
In ation rate & 26.0 & 15.4 & 11.4 & 7.4 & 5.1 & 3.8 & 2.8 & 3.4 & 1.5 \\
Unemployment rate & 5.7 & 4.4 & 5.9 & 5.4 & 7.2 & 8.3 & 7.4 & 7.7 & 9.8 \\
Mining production growth & 0.8 & 6.0 & 5.8 & 22.8 & 6.5 & 4.4 & 6.9 & 0.7 & 0.4
\end{tabular}

Source: International Monetary Fund.

Table (1) shows that the Chilean macroeconomy responds very quickly to external shocks. For example, in 1998 the GDP growth observed was $3.2 \%$, while two years before was $7.4 \%$. This decrease in growth can be explained by the Asian Financial Crisis (AFC) in 1997. Next, in 2009 there was a negative GDP growth, once again this may be explained by the Global Financial Crisis (GFC) started in 2008. From this table is also possible to observe the strong link between economic growth and employment, in which for the period 1990-2009, the lowest unemployment was reached in 1992 when Chile was growing at the very high level of $12.3 \%$. On the other hand, the highest unemployment level corresponds to the year after the GFC when Chile's economic growth was negative one percent. Mining production growth is also very responsive to external demand for minerals. This follows very closely episodes of international crises such as the AFC (1997) and the GFC (2008).

Table (2) shows the direct results of the rapid economic growth experience for Chile in the period 1989-2009. GDP per capita grew from a modest seven thousand 2005 dollars in purchasing power parity in 1990 to almost fourteen thousand 2005 dollars PPP in 2009. This represents an overall increase in welfare of two-folds in only two decades. Life expectancy also increased from 73.6 years to 78.8 years for the same period. Although, these aggregated numbers look very well, there is a dimension in which Chile has not 
performed so well. This weakness, for politicians and policymakers, is income inequality. Table (3) provides three measures of inequality. The first one is the Gini coefficient that allows us to get an overall idea of the inequality problems that this capitalist and small open economy faces.

TABle 2. InCOME AND health for Chile, I 990-2009.

\begin{tabular}{ccc} 
& $\begin{array}{c}\text { GDP per capita } \\
\text { PPP constant 2005\$ }\end{array}$ & $\begin{array}{c}\text { Life expectancy at birth } \\
\text { Total years }\end{array}$ \\
\hline 1990 & 6,936 & 73.6 \\
1992 & 8,108 & 74.2 \\
1994 & 8,848 & 74.8 \\
1996 & 10,186 & 75.3 \\
1998 & 10,906 & 76.0 \\
2000 & 11,029 & 76.8 \\
2003 & 11,698 & 77.9 \\
2006 & 13,248 & 78.4 \\
2009 & 13,832 & 78.8
\end{tabular}

Source: World Bank.

This table shows that the aggregate level of inequality in Chile has not changed significantly during the governments of the Coalition of Parties for Democracy. Despite their e orts, progressive fiscal policies were ineffective and the inequality levels remained statistically unchanged. On the other hand, absolute poverty declined significantly showing how economic growth plays an important role to alleviate poverty, but lacks of impact in matters of inequality.

Table 3. Measures of Inequality for Chile, i 990-2009.

\begin{tabular}{cccccccccc} 
& 1990 & 1992 & 1994 & 1996 & 1998 & 2000 & 2003 & 2006 & 2009 \\
\hline $\begin{array}{c}\text { Gini index } \\
\begin{array}{c}\text { Income share held } \\
\text { by highest 10\% }\end{array}\end{array}$ & 55.3 & 54.8 & 55.1 & 54.9 & 55.5 & 55.3 & 54.6 & 51.8 & 52.1 \\
$\begin{array}{c}\text { Income share held } \\
\text { by lowest 10\% }\end{array}$ & 1.27 & 1.42 & 1.29 & 1.33 & 1.25 & 1.31 & 1.37 & 1.55 & 1.53
\end{tabular}

Source: World Bank.

The same can be concluded using the income shares held by the highest $10 \%$ and the lowest $10 \%$. These shares are practically 
unchanged. Another striking feature from table (3) is not only the stable path of inequality but is also its degree. For example, in 2009 the highest $10 \%$ obtained the $42.8 \%$ of income, while the lowest $10 \%$ obtained only the $1.53 \%$. This is a clear sign that either the highest $10 \%$ is extremely productive or that there are important market failures such as high bargaining power by the business class, networks based on family background not merit or talent, moral hazard by legislators, or some unequal social structure from colonial times. Moreover, notice that inequality within the highest $10 \%$ is also very significant, where the top $1 \%$ obtained around $30 \%$ of total income (See Lopez et al. (2013)). The distribution basically replicates the structure for the whole country within this decile.

According to the OECD, the average public expenditures of its members in 2007 were $4.6 \%$ of the GDP. Chile was below this benchmark in this year, and during the period 2000 and 2009, the average for Chile has been around $4 \%$.

Table 4. Expenditures on Education in Chile, i 998-2009.

\begin{tabular}{ccc|cc}
\hline & $\begin{array}{c}\text { Public Exp. } \\
\text { \% of GDP }\end{array}$ & $\begin{array}{c}\text { Private Exp. } \\
\text { \% of GDP }\end{array}$ & $\begin{array}{c}\text { Pb.Exp. annual growth } \\
\%\end{array}$ & $\begin{array}{c}\text { Pr.Exp. annual growth } \\
\%\end{array}$ \\
\hline 1998 & 3.4 & 2.7 & - & - \\
1999 & 3.8 & 3.0 & 11.0 & 13.6 \\
2000 & 3.9 & 3.2 & 6.3 & 11.1 \\
2001 & 4.5 & 3.4 & 19.1 & 8.3 \\
2002 & 4.5 & 3.6 & 1.5 & 7.7 \\
2003 & 4.1 & 3.8 & -3.9 & 9.1 \\
2004 & 3.9 & 3.5 & -1.3 & -2.0 \\
2005 & 3.6 & 3.1 & -2.5 & -8.3 \\
2006 & 3.6 & 2.6 & 4.3 & 5.3 \\
2007 & 3.9 & 2.7 & 16.5 & 7.1 \\
2008 & 4.4 & 2.8 & 14.4 & 8.1 \\
2009 & 4.8 & 3.0 & 8.9 & 0.3 \\
\hline
\end{tabular}

Source: UNESCO-OECD-Eurostat (UOE) data collection on education statistics and World Bank.

Even more, in 2007 Chile was the country in the OECD with the lowest public expenditure per student. ${ }^{1}$ Table (4) also shows private expenditure on education that is comparable to public expenditures, but smaller. This is due to the high level of private-subsidized educational institutions in Chile. Notice that these data include all 
levels of education. If we look at only tertiary education, then the trend is reverse. That is, private expenditures are much larger than public ones. This obeys to the stage of development of the country. Chile still has needs to level primary and secondary education.

Thus, by looking at the years of the Coalition of Parties for Democracy, we may observe that Chile experienced stable economic growth, while reducing poverty. On the other hand, inequality did not reduce and Chile remained to be a commoditized economy highly dependent on copper. Hence, the country was doing fine. This is remarkable considering that Chile was transitioning from a political dictatorship into a democratic competitive system. Political actors seem that decided to advocate for political cooperation rather than parliamentary gridlock.

\section{THE MOdeL}

The model developed in this section is one of political cooperation for legal reforms based on Alesina (1988) and Spiller and Tommasi (2003). Next, we present the assumptions of the model.

(a) There are two political blocks $i=A, B$

(b) The game is infinitely repeated,

(c) Both blocks have the same discount factor $\delta \in[0,1]$,

(d) Both of them want to minimize their lifetime utility given by: $\sum_{t=0}^{\infty} \delta^{t} E\left[L_{i}\left(y_{i} \theta_{t}\right)\right]$ where $y_{t}$ is the policy at time $\mathrm{t}$ and $\theta_{t}$ is an exogenous shock at time t,

(e) For simplicity, the loss function is defined as $L_{i}\left(y_{i}, \theta_{t}\right)=\left[\left(y_{t}-y_{i}\right)-\theta\right]^{2}$ where $y_{i}$ is the preferred policy of political block $i$,

(f) The economic shock $\theta_{t}$ has zero mean and is iid,

(g) $y_{A} \neq y_{B}$ captures the elements of conflict, and $\theta_{t}$ captures the idea of common interest.

The recognition rule is defined as $\mu_{t}=i$ in the sense that political block $i$ decides $\mathrm{y}_{\mathrm{t}}$ in period t. The probabilities to this rule may be assigned as,

$$
\mathrm{P}\left(\mu_{t}=A\right)=\alpha
$$

$$
\mathrm{P}\left(\mu_{t}=B\right)=1-\alpha
$$


where $\alpha$ is the probability of being elected at time $t$, and hence being the decision or policy maker. Of course, $\alpha \in(0,1)$. Further, we assume that at $\mathrm{t}=0$ the political blocks can make some agreements. This is the so-called "contracting moment". With this setup, the next step is to analyze cooperation and non-cooperation between these two political coalitions or blocks.

\section{A. Cooperation}

The first best is obtained as follows,

$$
\min \sum_{t=0}^{\infty} \delta^{t} E\left(L_{A}\left(y_{t}, \theta_{t}\right)\right)+\sum_{t=0}^{\infty} \delta^{t} E\left(L_{B}\left(y_{t}, \theta_{t}\right)\right)
$$

Next,

$$
\begin{aligned}
L_{A}\left(y_{t} \theta_{t}\right)+L_{B}\left(y_{t} \theta_{t}\right) & =\left(y_{t}-y_{A}-\theta_{t}\right)^{2}+\left(y_{t}-y_{B}-\theta_{t}\right)^{2} \\
& =2 y_{t}^{2}+2 y_{A}^{2}-4 y_{t} \theta_{t}+2 \theta_{t}^{2}
\end{aligned}
$$

Thus, the minimization problem becomes,

$$
\min 2 \sum_{\mathrm{t}=0}^{\infty} \delta^{t} E\left(\mathrm{y}_{\mathrm{t}}^{2}-2 y_{t} \theta_{t}+\theta_{\mathrm{t}}^{2}\right)+\sum_{\mathrm{t}=0}^{\infty} \delta^{t} E\left(2 \mathrm{y}_{\mathrm{A}}^{2}\right)
$$

Since $E\left(2 y_{A}^{2}\right)=2 y_{A}^{2}$ is a constant. The problem is reduced to,

$$
\min 2 \sum_{\mathrm{t}=0}^{\infty} \delta^{t} E\left[\left(\mathrm{y}_{\mathrm{t}}-\theta_{t}\right)^{2}\right]
$$

This implies that $\mathrm{y}^{*}\left(\theta_{t}\right)=\theta_{t}$ for all $\mathrm{t}$. This value minimizes the expected loss through the whole game if and only if the two political blocks cooperate. In this case, with different recognition rules this result is unchanged.

\section{B. Non-COOPERATION}

The one-shot Nash Equilibrium (NE) is given by non-cooperation. Notice that the one-shot NE is always an equilibrium in the infinite repetition of the game. For the non-cooperation path the recognition rule plays a role. That is, $\mathrm{P}\left(\mu_{t}=A\right)=\alpha$ and $\mathrm{P}\left(\mu_{t}=B\right)=1-\alpha$.

The equilibrium strategy for political block $i$ in the noncooperation path is given by, 


$$
y_{t}^{1}=y_{i}-\theta_{t} \Longrightarrow y_{t}=y_{\mu t} \theta_{t}
$$

Without loss of generality, let $i$ be equal to $\mathrm{A}$, and using the assumption that $y_{A}=-y_{B}$. This could be interpreted, for instance, that one political block wants to increase taxes, while the other wants to reduce them. Thus,

and

$$
L_{A}^{A}\left(y_{t}, \theta_{t}\right)=L_{A}\left(y_{t}, \theta_{t} \mid \mu t=A\right)=0
$$

$$
L_{A}^{B}\left(\mathrm{y}_{\mathrm{t}}, \theta_{t}\right)=L_{A}\left(y_{t}, \theta_{t} \mid \mu t=B\right)=\left(2 y_{B}\right)^{2}
$$

The expected loss at time $\mathrm{t}$ can be written as,

$$
E\left[L_{A}\left(y_{i}, \theta_{t}\right)\right]=(1-\alpha)\left(2 y_{B}\right)^{2}
$$

Similarly, for political block B,

$$
E\left[L_{B}\left(y_{i}, \theta_{t}\right)\right]=\alpha\left(2 y_{B}\right)^{2}
$$

Therefore, the expected loss for the infinite game $\mathrm{V}^{\mathrm{N}}$ is given by,

$$
V_{A}^{N}=\frac{1-\alpha}{1-\delta}\left(2 y_{B}\right)^{2}
$$

For political block B, we obtain,

$$
V_{B}^{N}=\frac{\alpha}{1-\delta}\left(2 y_{B}\right)^{2}
$$

If coalitions are cooperating, but then one of them deviates at time $t$, we assume that the other coalition will apply a Grim-trigger strategy defined as follows,

$$
\mathrm{y}_{\mathrm{t}}^{\mathrm{i}}= \begin{cases}\theta_{t} & \text { if } y_{\tau}=\theta t \forall \tau<t \\ y_{i}+\theta_{t} & \text { if not }\end{cases}
$$

In general, the payoff along the equilibrium path of cooperation will be different for the two political blocks. Given that cooperation implies $y_{t}=\theta_{t}$ this entails to the following payoffs from cooperation,

$$
V_{A}^{2}=\frac{y_{A}^{2}}{1-\delta}
$$

For political block B is basically the same, that is,

$$
V_{B}^{2}=\frac{y_{B}^{2}}{1-\delta}
$$


Let $V_{i}^{D}$ be defined as the present value of the expected payoff from an opportunistic deviation,

$$
\begin{aligned}
& V_{A}^{D}=0+\delta V_{A}^{N}=\mathrm{V}_{\mathrm{A}}^{\mathrm{D}}=\delta \frac{1-\alpha}{1-\delta}\left(2 y_{B}\right)^{2} \\
& V_{B}^{D}=0+\delta V_{B}^{N}=\mathrm{V}_{\mathrm{B}}^{\mathrm{D}}=\delta \frac{\alpha}{1-\delta}\left(2 y_{B}\right)^{2}
\end{aligned}
$$

Next, compare the expected loss for the case in the equilibrium path of cooperation and the situation in which there is an opportunistic deviation that leads the game to non-cooperation. For political block A:

$$
V_{A}^{C} \leq V_{A}^{D} \Longrightarrow \delta_{A C} \geq \frac{1}{4(1-\alpha)}
$$

For political block B:

$$
V_{B}^{C} \leq V_{B}^{D}=\delta_{A C} \geq \frac{1}{4 \alpha}
$$

Notice that if $\alpha=1 / 2$, then $\delta_{A C}=\delta_{B C}=\delta \geq 1 / 2$. This result is coherent with the one in the political economy literature, namely, Spiller and Tommasi (2003).

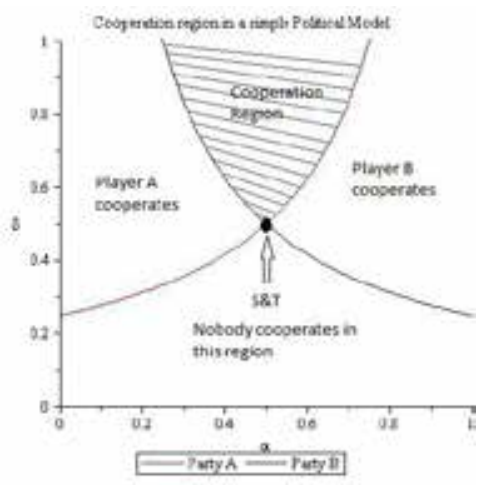

Figure 2. Cooperation Region.

Source: Author's numerical simulation. S\&T stands for Spiller and Tommasi (2003).

Given that the game is assumed to be with perfect information, there are only two regions: cooperation and non-cooperation. ${ }^{2}$ Figure 
(2) shows the cooperation region between the two political blocks. $\alpha$ is the recognition rule or probability of coalition A being elected. In a competitive political environment, as it was Chile during this period, it may be reasonable to assume that both coalitions have similar probabilities to win. Hence, $\alpha$ may be in a neighborhood of $1 / 2$. For this recognition rule for coalition $A$ the discount factor is exactly $1 / 2$. Therefore, if the political blocks are patient enough, that is, with discount factors greater than $1 / 2$ the political cooperation will occur. This implies that the parties will compromise in this infinite game, and therefore there will be gradual reform. This is exactly what we observe in the Chilean case during the governments of the Coalition of Parties for Democracy. The common interest of the two coalitions may be economic growth, while the difference in policy could be one in which one party advocates for progressive tax reform and the other one for tax cuts, or as it was the Chilean case, about reforms to address redistribution of income. In the long run with two political coalitions with the same probability of being elected the status quo should be the outcome. However, in the transition dynamics in which one political block gets elected for a few consecutive terms could be allowed to implement gradual progressive reforms affecting the distribution of income inequality in one direction or the other. In the inequality problem, initial conditions are essential, so if one coalition achieves small reforms may have a larger impact in the long run. The restriction to be in a competitive political system encourages cooperation for degrees of patience that do not need to be extremely high, and hence, alleviation of poverty and inequality may be more likely.

Next, suppose that the recognition rule is extremely high, say $\alpha=0,8$. That is, the probability of party A to be elected is $80 \%$. In this case, the level of patience required to cooperate is very high, almost a discount factor of 1 . This would imply that party A would try to implement its most preferred policy every time that is elected without compromising with the other party. This excess of power may lead to corruption of the ruling elite and emphasize of an ideological policy rather than a practical one to get reelected. This 
model explains relatively well the phenomenon observe in the USA and Chile. In both countries, there is a competitive political system in which the two main political coalitions (before the emergence of the "Frente Amplio", a third political block, in the year 2017) have to compromise in the long run, but with one common interest, not to harm economic growth.

\section{Conclusions}

We conclude that during the years of the Coalition of Parties for Democracy, there was strong cooperation between the two political blocks. The macroeconomic data show stable economic growth during this period; however, inequality was not properly addressed. The theoretical model presented supports the idea of political blocks being patient. This may be explained because of a slightly higher probability to win elections by the CDP, in contrast to situations in which one political block may have an overwhelming advantage. In addition, there is a deterrence effect to rapid reform caused by keeping the former dictator as a Commander in Chief of the army since 1989 to 1998 and as a designated senator from 1998 to 2002.

The data on inequality provide strong evidence of some sort of "structural" inequality that deserves attention and need to be further explained. There is also a strong link between economic growth and poverty, but this relationship between inequality and growth is inconclusive for the case of Chile. However, comparing Chile with other developing economies that experienced rapid economic growth, we could conjecture that unchanged income inequality may not be a negative outcome. Other countries became more unequal under similar situations; China is the best example of this.

Chile needs political cooperation to grow economically and socially. Recovering the cooperative path experienced in the years of the Coalition of Parties for Democracy seems to be the way forward. Polarization will lead this small open economy to inefficient outcomes such as small economic growth, stagnation of poverty reductions and income inequality increases. 


\section{REFERENCES}

AGOSTINI, Claudio A., Philip H. Brown, and Andrei C. Roman. 2010. "Poverty and Inequality Among Ethnic Groups in Chile". World Development, 38(7): 1036-1046.

ALBERTUS, Michael, and Victor Menaldo. 2016. "Capital in the Twenty-First Century in the Rest of the World". Annual Review of Political Science, 19: 49-66.

ALESINA, Alberto. 1988. "Credibility and policy convergence in a two-party system with rational voters." The American Economic Review, 78(4): 796-805.

ALESINA, Alberto, and Dani Rodrik. 1994. "Distributive Politics and Economic Growth". The Quarterly Journal of Economics, 109(2): 465-490.

BARRO, Robert. 1991. "Economic Growth in a Cross Section of Countries". The Quarterly Journal of Economics., 106(2): 407-443.

BARRO, Robert. 2000. "Inequality and Growth in a Panel of Countries". Journal of Economic Growth, 5(1): 5-32.

BARRO, Robert, and Jong-Wha Lee. 2001. "International Data on Educational Attainment: Updates and Implications". Oxford Economic Papers, 53(3): 541-563.

BENHABIB, Jess, and Mark M. Spiegel. 1994. "The role of human capital in economic development: Evidence from aggregate cross-country data”. Journal of Monetary Economics., 34(2): 143-173.

BERTOLA, Giuseppe. 1993. "Factor Shares and Savings in Endogenous Growth". The American Economic Review, 83(5): 1184-1198.

CONTRERAS, Dante. 2003. "Poverty and inequality in a rapid growth economy: Chile 1990-96". The Journal of Development Studies, 39(3): 181-200.

DAVID, Anda Mariana; and Mohamed Ali Marouani. 2012. "Poverty Reduction and Growth Interactions: What Can Be Learned from the Syrian Experience?" Development Policy Review, 30(6): 773-787.

DEININGER, Klaus, and Lyn Squire. 1997. "Economic Growth 
and Income Inequality: Reexamining the Links.” Finance \& Development, 34(1): 38-41.

FAN, Shenggen. 2008. Public expenditures, growth, and poverty: lessons from developing countries. Baltimore: Johns Hopkins University Press.

FLEISHER, Belton M, Haizheng Li, Li Shi, and Xiaojun Wang. 2005. "Sorting, selection, and transformation of the return to college education in China". Working Paper, University of Hawaii at Manoa.

FORBES, Kristin. 2000. "A Reassessment of the Relationship between Inequality and Growth.” American Economic Review, 90(4): 869-887.

GOUDIE, Andrew, and Paul Ladd. 1999. "Economic growth, poverty and inequality". Journal of International Development, 11(2): 177-195.

KRSTIC, Gorana, and Peter Sanfey. 2011. "Earnings inequality and the informal economy". Economics of Transition, 19(1): 179-199.

LI, Hongyi, and Heng-fu Zou. 1998. "Income Inequality is not Harmful for Growth: Theory and Evidence". Review of Development Economics, 2(3): 318-334.

LOCKWOOD, Ben, and Alan Manning. 1988. "Inequality And Ine ciency In A Model Of Occupational Choice With Asymmetric Information”. Journal of Public Economics, 37(2): 147-169.

LOPEZ, Ramon, Eugenio Figueroa, Pablo Gutierrez, et al. 2013. "La parte del león: Nuevas estimaciones de la participación de los super ricos en el ingreso de Chile". Serie Documentos de Trabajo, 379: 1-32.

LUCAS, Robert. 1988. "On The Mechanics Of Economic Development”. Journal of Monetary Economics, 22(1): 3-42.

MAYER, Susan. 2010. "The relationship between income inequality and inequality in schooling". Theory and Research in Education, 8(1): 5-20.

PERSSON, Torsten, and Guido Tabellini. 1994. "Is Inequality Harmful for Growth?" The American Economic Review, 84(3): 600-621. 
REHME, Gunther. 2007. "Education, Economic Growth and Measured Income Inequality". Economica, 74(295): 493-514. ROJAS-VALLEJOS, Jorge, and Stephen J Turnovsky. 2017. “Tariff Reduction and Income Inequality: Some Empirical Evidence”. Open Economies Review, 28(4): 603-631.

SCHILLER, Bradley. 1984. The economics of poverty and discrimination. 4th ed., Engle-wood Cliffs NJ: Prentice-Hall. SCHNEIDER, Friedrich. 2002. "Size and measurement of the informal economy in 110 countries". Working Paper, Australian National University.

SPILLER, Pablo T, and Mariano Tommasi. 2003. "The institutional foundations of public policy: a transactions approach with application to Argentina”. Journal of Law, Economics, and Organization, 19(2): 281-306.

WELLER, Christian. 2007. "The Benefits of Progressive Taxation in Economic Development". Review of Radical Political Economics, 39(3): 368-376.

WODON, Quentin T. 2000. "Microdeterminants of consumption, poverty, growth, and inequality in Bangladesh". Applied Economics, 32(10): 1337-1352.

Notas de PÁGina

${ }^{1}$ OECD Family Database. Social Policy Division at the Directorate of Employment, Labour and Social Affairs.

2 The region where only one player cooperates becomes a noncooperation region because cooperation is not a best response when the other player does not. However, in a game with imperfect information, cooperation might be seen as a signal to the other player. This situation is not analyzed in this model.

Fecha de Recepción del Artículo: 28 de mayo de 2018 Fecha de Aceptación: 29 de junio de 2018 